\title{
PENGARUH KOMUNIKASI NONVERBAL DOSEN TERHADAP MINAT BELAJAR MAHASISWA
}

\author{
Abdul Haliq dan Mardiyanah Nasta \\ Fakultas Bahasa dan Sastra Universitas Negeri Makassar \\ Jl. Daeng Tata Raya, Kampus Parangtambung \\ Email: abdulhaliq88@gmail.com
}

\begin{abstract}
Effect of Interest Nonverbal Communication Teaching Students Learn. The aim of this research was to determine the effect of nonverbal communication lecturer to student interest in learning the Indonesian education courses. The approach in this study is a quantitative research. The research was conducted on two different courses, namely Indonesian Education Program. These courses are within the scope of the Faculty of Languages and Literature, University of Makassar. In this study, data collection was done by questionnaire and interview. The data collection was conducted to obtain data on the effect of nonverbal communication to the interest of students learning Indonesian Education Faculty of Languages and Literature, University of Makassar force in 2014. In this study, the data collected through questionnaires and interviews were subsequently analyzed by quantitative descriptive and to use the influence menanalisis SPSS program in order to determine the extent of nonverbal communication pengruh lecturer with student motivation to learn. Results of linear regression analysis to test the hypothesis indicates that the value $\mathrm{t}$ count $>\mathrm{t}$-table $(8072>2363)$. From the test results concluded that there is significant influence between nonverbal communication lecturer to student interest in learning.
\end{abstract}

\begin{abstract}
Abstrak: Pengaruh Komunikasi Nonverbal Dosen Terhadap Minat Belajar Mahasiswa. Tujuan yang ingin dicapai dalam penelitian ini adalah untuk mengetahui pengaruh komunikasi nonverbal dosen terhadap minat belajar mahasiswa program studi pendidikan bahasa Indonesia. Pendekatan dalam penelitian ini merupakan penelitian kuantitatif. Penelitian ini dilaksanakan pada dua program studi yang berbeda, yaitu Program Studi Pendidikan Bahasa Indonesia. Program studi ini berada dalam ruang lingkup Fakultas Bahasa dan Sastra Universitas Negeri Makassar. Dalam penelitian ini, pengumpulan data dilakukan dengan cara Angket dan wawancara. Pengumpulan data ini dilakukan untuk memeroleh data mengenai pengaruh komunikasi nonverbal terhadap minat belajar mahasiswa Pendidikan Bahasa Indonesia Fakultas Bahasa dan Sastra, Universitas Negeri Makassar angkatan 2014. Dalam penelitian ini, data yang terkumpul melalui angket dan wawancara selanjutnya dianalisis dengan deskriptif kuantitatif dan untuk menanalisis pengaruh digunakan bantuan program SPSS dalam rangka untuk mengetahui sejauh mana pengruh komunikasi nonverbal dosen dengan motivasi belajar mahasiswa. Hasil analisis uji regresi linear untuk menguji hipotesis yang diajukan menunjukkan bahwa nilai t-hitung $>$ t-tabel $(8.072>$ 2.363). Dari hasil uji tersebut disimpulkan bahwa terdapat pengaruh yang signifikan antara komunikasi nonverbal dosen terhadap minat belajar mahasiswa.
\end{abstract}

Kata kunci: Komunikasi nonverbal, minat belajar, pengaruh, signifikan.

Komunikasi merupakan penyampaian pesan oleh komunikator atau orang yang melaksanakan komunikasi. Komunikasi akan berjalan jika terdapat dua orang yang melakukan kegiatan komunikasi. Komunikasi biasanya bertujuan untuk menyampaikan pesan, gagasan, ide, ataupun maksud kepada orang lain.
Komunikasi ini memiliki dampak atau efek terhadap orang yang melaksanakan komunikasi. Begitupun dengan proses pembelaajran, terdapat kegiatan komunikasi di dalamnya. Proses belajar mengajar merupakan suatu bentuk komunikasi yaitu komunikasi antara subyek didik dengan pendidik, antara siswa dengan guru, antara 
mahasiswa dengan dosen (Pasmada, 2012). Tujuan dilaksanakannya komunikasi dalam proses belajar-mengajar yaitu untuk mengomunikasikan pengetahuan dosen kepada mahasiswa, tujuan ini bersifat khas karena ada proses belajar di dalamnya, yaitu menyampaikan sesuatu yang membuat mahasiswa yang terlibat dalam pembelajaran yang tadinya tidak tahu menjadi tahu. Tujuan dari proses pembelajaran akan tercapai jika prosesnya berlangsung secara komunikatif, artinya terjadi komunikasi yang efektif dan efisien antara guru dan siswa atau dosen dengan mahasiswa. dalam proses komunikasi ada dua hal yang terlibat yaitu kemampuan verbal dan kemampuan nonverbal. Kedua kemampuan ini sangat dibutuhkan oleh komunikan dalam mengomunikasikan sesuatu.

Sebagai suatu proses akademik, dosen mengajar dengan maksud untuk mengomunikasikan tiga (3) hal yang tidak terpisahkan, yaitu pengetahuan, keterampilan, dan sikap melalui dua cara yang integratif, yaitu verbal dan non-verbal. Secara verbal, dosen menyajikan materi untuk memfasilitasi pemahaman peserta didik dengan bahasa pengajaran yang jelas, sederhana, menarik, efektif dan produktif yang tentunya dibingkai dengan kompetensi baik linguistik, yaitu Fonologi, Morfologi, Sintaks, Semantik, dan Pragmatik dan maupun kompetensi nonlinguistik (Muhayyang, 2010). Salah satu upaya yang dilakukan oleh pengajar dalam memaksimalkan proses komunikasi dalam pembelajaran yaitu dengan memadukan komunikasi verbal dan nonverbal. Komunikasi verbal identik dengan penggunaan bahasa berupa ujaran yang keluar dari alat ucap seseorang, sedangkan komunikasi nonverbal berupa ekspresi wajah, bahasa tubuh, posisi berdiri dan duduk, kontak mata, suara, dan proksimiti. Kedua jenis komunikasi ini akan saling mendukung dalam penyampaian pesan oleh pengajar kepada siswa/mahasiswanya.

Berkaitan dengan komunikasi nonverbal dosen di dalam kelas, Richmond dan Mc Croskey in Hsu (2006) mengatakan bahwa komunikasi tersebut merupakan salah satu cara yang bisa memperkuat sikap positif para pembelajar bahasa yang harus dimanfaatkan dosen untuk menciptakan suatu lingkungan belajar yang nyaman bagi mereka.

Berdasarkan uraian tersebut, bentuk komunikasi nonverbal sangat penting untuk digunakan oleh seorang dosen dalam melaksanakan kegiatan komunikasi dengan siswa/mahasiswa di dalam kelas. Oleh karena itu, peneliti merasa perlu meneliti pengaruh komunikasi nonverbal terhadap minat belajar mahasiswa.

\section{METODE PENELITIAN}

Pendekatan dalam penelitian ini merupakan pendekatan kuantitatif. Penelitian ini dilaksanakan Program Studi Pendidikan Bahasa Indonesia. Program studi ini berada dalam ruang lingkup Fakultas Bahasa dan Sastra Universitas Negeri Makassar.

Populasi penelitian ini adalah mahasiswa pendidikan bahasa Indonesia angkatan 2014 yang berjumlah 85 orang. Keseluruhan mahasiswa tersebut terbagi ke dalam tiga kelas. Karena populasi dalam penelitian ini relatif kecil yaitu 85 orang, dan semua populasi tersebut dapat dijangkau oleh peneliti, maka semua populasi tersebut masuk ke dalam sampel. Pengumpulan data dilakukan dengan cara Angket. Pengumpulan data ini dilakukan untuk memeroleh data mengenai pengaruh komunikasi nonverbal terhadap minat belajar mahasiswa Pendidikan Bahasa Indonesia Fakultas Bahasa dan Sastra, Universitas Negeri Makassar angkatan 2014.

Data yang terkumpul melalui angket dan wawancara selanjutnya dianalisis dengan deskriptif kuantitatif dan untuk menanalisis pengaruh digunakan bantuan program SPSS dalam rangka untuk mengetahui sejauh mana pengruh komunikasi nonverbal dosen dengan motivasi belajar mahasiswa.

\section{HASIL PENELITIAN}

Komunikasi nonverbal merupakan komunikasi yang lazim digunakan oleh seseorang dalam praktek komunikasi lisan. Komunikasi nonverbal dapat digunakan sebagai pendukung komunikasi lisan ataupun dapat digunkan sebagai pengganti komunikasi verbal (lisan). Artinya, dengan menggunakan komunikasi nonverbal saja sudah dapat mengirim pesan kepada orang lain. Tentunya bahasa nonverbal tersebut juga dipahami oleh lawan tutur. 
Begitu pula halnya dalam proses pembelajaran. Komunikasi nonverbal juga menjadi salah satu bagian yang penting untuk diperhatikan. Hal ini dikarenakan, bentuk komunikasi nonverbal yang digunakan akan sangat mendukung dalam penyampaian pesan.

\section{Tanggapan Mahasiswa Terhadap Komunikasi Nonverbal Dosen}

Dari hasil olah data, diperoleh nilai ratarata yaitu 4,38 untuk angket komunikasi nonverbal dosen. Hal ini berarti, untuk tanggapan masiswa terhadap komunikasi nonverbal dosen berada pada kategori sangat baik. Hal ini diperoleh dari lebar skala penilaian yang berada pada skla 4,24 - 5.00. Hal ini menujukkan bahwa komunikasi nonverbal dosen sangat diperlukan mahasiswa dalam proses perkuliahan demi kelancaran perkuliahan yang dilaksanakan oleh dosen.

\section{Tanggapan Mahasiswa terhadap minat belajar}

Dari hasil olah data pada tabel di atas diperoleh nilai rata-rata yaitu 4,03. Hal ini berarti, untuk angket minat belajar terhadap komunikasi nonverbal dosen berada pada kategori baik. Hal ini diperoleh dari lebar skala penilaian yang berada pada skala 3,43 - 4,23. Hal ini menujukkan bahwa minat belajar terhadap komunikasi nonverbal dosen secara deskriptif memiliki pengaruh yang baik. Artinya bahwa minat belajar mahasiswa dapat ditumbuhkan dengan memaksimalkan komunikasi nonverbal dosen.

\section{Uji Hipotesis}

Hubungan antara dua variabel yaitu variabel komunikasi nonverbal dan variabel minat belajar mahasiswa diukur dengan menggunakan uji hipotesis. Hal ini dilakukan untuk mengetahui hubungan yang signifikan antara komunikasi nonverbal dan minat belajar mahasiswa. Untuk mengetahui hubungan tersebut digunakan uji hipotesis menggunakan bantuan program komputer yaitu program SPSS. Jenis analisis yang digunakan yaitu analisis regresi linear.

Untuk nilai t-tabel dicari pada $\alpha=5 \%$ : $2=2,5 \%$ (uji 2 sisi) dengan derajat kebebasan (df) n-k-1 atau 10-2-1 = 7 (n adalah jumlah kasus dan $\mathrm{k}$ adalah jumlah variabel independen). Dengan pengujian 2 sisi (signifikansi $=0,025$ ) hasil diperoleh untuk $t$ tabel sebesar 2.363. Dari hasil analisis yang tampak pada tabel di atas diperoleh nilai t-hitung yaitu 8.072. Karena nilai t-hitung $>$ t-tabel $(8.072>2.363)$ maka Ho ditolak artinya bahwa ada pengaruh signifikan antara komunikasi nonverbal dosen dengan minat belajar mahasiswa. jadi, pada penelitian ini dapat disimpulkan bahwa komunikasi nonverbal berpengaruh terhadap minat belajar mahasiswa.

\section{PEMBAHASAN}

Kesuksesan pemebeljaran di kelas tidak hanya dilihat dari kedalaman materinya, namun perlu melihat banyak aspek baik dari dosen ataupun mahasiswanya. Kedua variabel yang terlibat dalam proses pembelajaran ini merupakan variabel yang sangat penting untuk mengukur kesuksesan proses pembelajaran di kelas. Kedua variabel ini harus saling mendukung demi terciptanya iklim belajar yang baik di dalam kelas.

Berkaitan dengan iklim belajar yang bai di dalam kelas, fungsi dosen sebagai tenaga pengajar menjadi salah satu objek vital dalam menciptakan iklim belajar yang baik. Hal ini dikarenakan dosen sebagai pengajar menjadi bagian yang penting dalam mengarahkan pembelajaran di kelas. Begitu pula halnya dengan pemilihan metode pembelajaran dan cara mengajar dosen seluruhnya ditentukan oleh dosen yang bersangkutan. Sehingga, dapat dikatakan bahwa salah satu cara untuk mencapai iklim belajar yang baik terletak pada cara dosen dalam mengelola dan menyajikan pembelajaran dengan baik.

Pengelolaan kelas yang baik oleh dosen dapat memberikan dampak yang baik pula bagi mahasiswa. Salah satu bagian dari pengeloaan kelas tersebut terkait dengan cara dosen dalam menjelaskan materi perkuliahan. Dosen yang memberikan penjelasan dengan baik akan mempermudah mahasiswa untuk mengerti materi penjelasan yang diberikan oleh dosen. dengan demikian mahasiswa dapat memahami materi perkuliahan.

Penggunaan bahasa nonverbal oleh dosen maerupakan salah satu cara yang dilakukan oleh dosen dalam menjelaskan materi. 
Penggunaan bentuk komunikasi nonverbal ini diharapkan dapat memberikan dampak positif bagi mahasiswa, terutama dalam kaitannya dengan minat belajar. Mahasiswa yang memiliki minat belajar yang baik dapat dengan mudah mengikuti proses perkuliahan dengan baik pula. Dengan demikian, minat belajar sangat berperan penting dalam kesuksesan belajar mahasiswa.

Hasil penelitian yang dilakukan pada mahasiswa PBSI terkait dengan pengaruh komunikasi nonverbal dosen terhadap minat belajar menunjukkan bahwa ada pengaruh yang signifikan antara komunikasi nonverbal dosen terhadap minat belajar mahasiswa. Kesimpulan ini diperoleh setelah melakukan analisis regresi linear menggunakan program SPSS dan diperoleh nilai t-hitung yaitu 8.072. Nilai ini kemudian dibandingkan dengan nilai t-tabel untuk mengetahui apakah terdapat pengaruh atau tidak. Karena t-hitung $>$ t-tabel $(8.072>2.363)$ maka terdapat pengaruh yang signifikan.

Jika dilihat pada hasil analisis skala Likert diperoleh bahwa untuk angket komunikasi nonverbal dosen diperoleh nilai rerata yaitu 4.38 dan untuk angket minat belajar diperoleh nilai rerata yaitu 4.03. Nilai rerata angket komunikasi nonverbal berada pada kategori sangat baik dan nilai rerata minat belajar berada pada kategori baik. Ini berarti bahwa mahasiswa memerlukan

komunikasi nonverbal dosen dalam menumbuhkan minat belajar.

Komunikasi nonverbal merupakan salah satu komponen yang menumbuhkan minat belajar mahasiswa. Berkenaan dengan hal tersebut, Richmond dan Mc Croskey in Hsu (2006) mengatakan bahwa komunikasi tersebut merupakan salah satu cara yang bisa memperkuat sikap positif para pembelajar

\section{DAFTAR PUSTAKA}

Arikunto, S. 2006. Prosedur Penelitian: Suatu Pendekatan Praktik. Jakarta: PT. Rineka Cipta.

Hsu, L. L. (2006). The relationship among teachers' verbal and nonverbal immediacy behaviors and students' willingness to speak in English in central Taiwanese college classrooms. Unpublished doctoral dissertation, Oral Roberts University, Tulsa, Oklahoma. bahasa yang harus dimanfaatkan dosen untuk menciptakan suatu lingkungan belajar yang nyaman bagi mereka.

Komunikasi nonverbal merupakan salah satu instrumen penting untuk menciptkan iklim belajar yang positif. Berkenaan dengan minat belajar, mahasiswa lebih senang dan merasa termotivasi untuk mengikuti perkuliahan di dalam kelas bagi dosen yang menggunakan komunikasi nonverbal sebagai bentuk dukungan dari komunikasi verbal yang digunakan ketika mengajar.

\section{KESIMPULAN}

Berdasarkan hasil yang diperoleh berdasarkan analisis data maka dapat disimpulkan bahwa:

1. Hasil analisis terhadap hasil penelitian pada data yang bersal dari kuesioner diperoleh bahwa nilai rata-rata untuk kuesioner komunikasi nonverbal dosen yaitu 4,38 dan berkategori sangat baik. Nilai rata-rata untuk kuesioner minat belajar mahasiswa yang dipengaruhi komunikasi nonverbal dosen yaitu 4,03 dan berkategori baik.

2. Hasil analisis uji regresi linear untuk menguji hipotesis yang diajukan menunjukkan bahwa nilai t-hitung $>$ ttabel $(8.072>2.363)$.

3. Dari hasil uji tersebut disimpulkan bahwa terdapat pengaruh yang signifikan antara komunikasi nonverbal dosen terhadap minat belajar mahasiswa.

Muhayyang, Maemuna. 2010. Lecturer and student talk in classroom interaction: classroom management scheme. Unpublished dissertation. Unhas.

Pasmada, Indah. 2012. Peran Komunikasi yang Efektif dalam Pembelajaran. http://indahcip.blogspot.com/2012/05/perankomunikasi-yang-efektif-dalam.html. 
Purnomo, Nurul Hudha. 2011. "Hubungan Kemenarikan Gaya Mengajar Dosen dan Minat Belajar dengan Prestasi Belajar Mahasiswa Jurusan Administrasi Pendidikan Fakultas Ilmu Pendidikan Universitas Negeri Malang." Skripsi. Universitas Negeri Malang. $\quad$ http://karyailmiah.um.ac.id/index.php/ASP/article/view/ $\underline{14972}$

Sugiyono. 2011. Metode Penelitian Kuantitatif Kualitatif dan $R \& D$. Bandung: Alfabeta.

Sitompul, Nurmida Catherine. 2009. Perilaku Komunikasi Nonverbal Guru dalam Kelas Pembelajaran. Internet. Diakses pada tanggal $14 \quad$ Maret 2015. http://digilib.unipasby.ac.id/files/disk1/5/gdl hub--nurmidacat-224-1-nurmida2.pdf

Sullivan, Muthia. Komunikasi Nonverbal. Internet. Diakses pada tanggal 14 Maret. http://www.academia.edu/9810109/komunik asi_non_verbal
Tarigan, Enda Amelia. 2012. "Hubungan Prilaku Nonverbal Guru di Dalam Kelas dengan Hasil Belajar Biologi Siswa pada Materi Ekosistem Kelas x sma negeri 2 Binjai t.p. 2011/2012”. Skripsi. FMIPA UNIMED.

Trisulaminah. 2010. "Pengaruh Kreativitas dan Minat Belajar Siswa Terhadap Prestasi Belajar IPS Siswa Kleas X SMA Negeri 1 Gemolong Tahun Ajaran 2009/2010.” Skripsi. FKIP. Universitas Sebelas Maret Surakarta.

Uma, Hasminee. 2013. Persepsi: Pengertian, Definisi, dan Faktor yang Mempengaruhi. Internet. Diakses pada tanggal 17 Maret 2014.

http://bahasa.kompasiana.com/2013/10/20/ persepsi-pengertian-definisi-dan-factoryang-mempengaruhi-600802.html

Yusuf, A. Muri. 2014. Metode Penelitian: Kuantitatif, Kualitatif, dan Penelitian Gabungan. Jakarta: Prenadamedia Group. 